Article

\title{
Facile synthesis of Fe-containing graphitic carbon nitride materials and their catalytic application in direct hydroxylation of benzene to phenol
}

\author{
Bing Xue, Ye Chen, Yin Hong, Ding-Yang Ma, Jie Xu *, Yong-Xin Li \# \\ Jiangsu Key Laboratory of Advanced Catalytic Materials and Technology, School of Petrochemical Engineering, Changzhou University, Changzhou \\ 213164, Jiangsu, China
}

\section{A R T I C L E I N F O}

\section{Article history:}

Received 19 January 2018

Accepted 19 March 2018

Published 5 July 2018

\section{Keywords:}

Benzene

Hydroxylation

Graphitic carbon nitride

Phenol

\begin{abstract}
A B S T R A C T
Fe-containing graphitic carbon nitride $\left(\mathrm{Fe}-\mathrm{g}-\mathrm{C}_{3} \mathrm{~N}_{4}\right)$ materials were synthesized via one-step pyrolysis of $\mathrm{FeCl}_{3}$ and dicyandiamide. The physicochemical properties of the synthesized Fe-g- $\mathrm{C}_{3} \mathrm{~N}_{4}$ samples were characterized by $\mathrm{N}_{2}$ adsorption-desorption, X-ray diffraction, thermal gravimetric, Fourier transform infrared, UV-vis diffuse reflectance, X-ray photoelectron spectroscopy, and transmission electron microscopy. The Fe cations were anchored by nitrogen-rich $\mathrm{g}-\mathrm{C}_{3} \mathrm{~N}_{4}$, whereas the graphitic structures of $\mathrm{g}_{-} \mathrm{C}_{3} \mathrm{~N}_{4}$ were retained after the introduction of Fe. As heterogeneous catalysts, Fe-g- $\mathrm{C}_{3} \mathrm{~N}_{4}$ exhibited good catalytic activity in the direct hydroxylation of benzene to phenol with $\mathrm{H}_{2} \mathrm{O}_{2}$, affording a maximum yield of phenol of up to $17.5 \%$. Compared with other Fe- and V-containing g- $\mathrm{C}_{3} \mathrm{~N}_{4}$ materials, Fe-g- $\mathrm{C}_{3} \mathrm{~N}_{4}$ features a more convenient preparation procedure and higher catalytic productivity of phenol.
\end{abstract}

(C) 2018, Dalian Institute of Chemical Physics, Chinese Academy of Sciences. Published by Elsevier B.V. All rights reserved.

\section{Introduction}

As an important commodity chemical, phenol is extensively used for the manufacture of phenol resins, caprolactam, adipic acid, dyestuffs, pesticides $[1,2]$, etc. The three-step cumene process is the main approach for the synthesis of phenol and contributes with more than $90 \%$ of the global output of phenol. However, the conventional industrial synthetic route suffers from several drawbacks including high-energy consumption, low one-pass yield of phenol $(\sim 5 \%$, based on the initial benzene quantity), and dependence on the market of acetone [3-5]. In the past decade, several new synthetic strategies have been proposed for the production of phenol. Among them, the direct hydroxylation of benzene, featuring an environmentally benign procedure, has been commonly proposed as the catalytic process with the most potential for the manufacture of phenol $[3,6]$.

A series of oxidant agents including air, oxygen, $\mathrm{N}_{2} \mathrm{O}$, and $\mathrm{H}_{2} \mathrm{O}_{2}$ have been employed for the direct hydroxylation of benzene $[7,8]$. Although either air or oxygen is very cheap and widely available, the catalytic activity in such a process is very low and far from industrial implementation [9]. Furthermore, the main restriction for the industrial implementation of $\mathrm{N}_{2} \mathrm{O}$ is its complicated operational technology [3]. In contrast, the use

\footnotetext{
* Corresponding author. Tel: +86-519-86330135; E-mail: shine6832@163.com

\# Corresponding author. Tel: +86-519-86330135; E-mail: liyxluck@163.com

This work was supported by the National Natural Science Foundation of China (21673024), Advanced Catalysis and Green Manufacturing Collaborative Innovation Center (ACGM2016-06-28), Foundation of State Key Laboratory of High-efficiency Utilization of Coal and Green Chemical Engineering (2017-K28), and the Top-notch Academic Programs Project of Jiangsu Higher Education Institutions (PPZY2015B145).

DOI: 10.1016/S1872-2067(18)63063-3 | http://www.sciencedirect.com/science/journal/18722067 | Chin. J. Catal., Vol. 39, No. 7, July 2018
} 
of $\mathrm{H}_{2} \mathrm{O}_{2}$ as an oxidant for the transformation from benzene to phenol demands milder reaction conditions together with a simpler process than its counterparts. Simultaneously, water is, ideally, the sole co-product [10]. Therefore, the direct hydroxylation of benzene under $\mathrm{H}_{2} \mathrm{O}_{2}$ has received tremendous attention in the field of phenol synthesis. Nevertheless, phenol can be over-oxidized to produce hydroquinone and benzoquinone. In this sense, it is still a hot topic to develop a robust catalyst that can provide excellent activity along with high selectivity to the target molecule.

A variety of heterogeneous catalysts, including titanium silicalite sieves (TS-1) [11,12], heteropolyacids (HPAs) [2,5,6], metal oxides supported on mesoporous materials $[1,2,13]$, and transition metals incorporated into molecular sieves [7], have been extensively employed for the direct hydroxylation of benzene. In the past decade, graphitic carbon nitride $\left(g-\mathrm{C}_{3} \mathrm{~N}_{4}\right)$ has attracted tremendous attention as a new type of catalyst in both thermal catalysis $[14,15]$ and photocatalysis [16,17]. In particular, because of its unique capacity to activate the benzene molecule, g- $\mathrm{C}_{3} \mathrm{~N}_{4}$ (especially mesoporous g- $\mathrm{C}_{3} \mathrm{~N}_{4}$ ) has demonstrated potential catalysis in several benzene-involved reactions, including alkylation [18], acylation [19,20], and oxidation of benzene [21-23]. Recently, our group has synthesized mesoporous g- $\mathrm{C}_{3} \mathrm{~N}_{4}$ materials, which were then loaded with vanadyl(IV) acetylacetonate [VO(acac) 2] [24] and vanadia [8]. The results showed that such $\mathrm{g}-\mathrm{C}_{3} \mathrm{~N}_{4}$-based composites were able to promote the direct hydroxylation of benzene under $\mathrm{H}_{2} \mathrm{O}_{2}$, with a maximum yield of phenol of about $18 \%$.

Although mesoporous g- $\mathrm{C}_{3} \mathrm{~N}_{4}$ catalysts possessed high surface areas and exhibited promising catalysis in benzene-activating reactions, all the reported mesoporous g- $\mathrm{C}_{3} \mathrm{~N}_{4}$ supports have been prepared by a nanocasting method, with silica materials as hard templates $[19,25,26]$. This preparation demanded a silica-etching procedure with a volatile and toxic $\mathrm{HF}$ or $\mathrm{NH}_{4} \mathrm{HF}_{2}$ solution, which was time-consuming and not environmentally friendly $[15,27,28]$. To circumvent these issues we, very recently, developed vanadia catalysts supported on exfoliated g- $\mathrm{C}_{3} \mathrm{~N}_{4}$ nanosheets, which were more conveniently synthesized than mesoporous g- $\mathrm{C}_{3} \mathrm{~N}_{4}$ [29]. However, the final catalytic activity of such catalysts in the hydroxylation of benzene is still not satisfactory. On the other hand, the transition metal halides represented by $\mathrm{FeCl}_{3}$, are the typical Lewis acids which are extensively used in benzene-activating reactions [30,31]. In this work, a facile and rapid method to prepare Fe-containing g- $\mathrm{C}_{3} \mathrm{~N}_{4}$ materials was developed via one-step pyrolysis of $\mathrm{FeCl}_{3}$ and dicyandiamide. As heterogeneous catalysts, the Fe-g- $\mathrm{C}_{3} \mathrm{~N}_{4}$ materials catalyzed the direct hydroxylation of benzene under $\mathrm{H}_{2} \mathrm{O}_{2}$ with good catalytic activities, affording a maximum yield of phenol of as much as $17.5 \%$ at a reaction time of $2 \mathrm{~h}$.

\section{Experimental}

\subsection{Catalyst preparation}

$\mathrm{FeCl}_{3}(0.15 \mathrm{~g})$ and dicyandiamide (DCDA, $\left.4.00 \mathrm{~g}\right)$ were added into $100 \mathrm{~mL}$ of ethanol, and then refluxed at $80{ }^{\circ} \mathrm{C}$ for $3 \mathrm{~h}$.
The solution was dried at $60{ }^{\circ} \mathrm{C}$ until removal of ethanol and formation of a dark yellow solid. After being ground, the yellow powder was calcined under $\mathrm{N}_{2}$ atmosphere at $550{ }^{\circ} \mathrm{C}$ for $4 \mathrm{~h}$, and the resultant solid was designated as $m \mathrm{Fe} / \mathrm{g}-\mathrm{C}_{3} \mathrm{~N}_{4}$ catalyst, where $m$ indicated the weight percentage of $\mathrm{Fe}$ of $\mathrm{g}-\mathrm{C}_{3} \mathrm{~N}_{4}$.

\subsection{Catalyst characterization}

X-ray diffraction (XRD) patterns were collected on a D8 Advance (Bruker) X-ray diffractometer equipped with a graphite monochromator $(40 \mathrm{kV}, 40 \mathrm{~mA})$ using $\mathrm{Ni}$-filtered $\mathrm{Cu}-K_{\alpha}$ radiation $(\lambda=1.5418 \AA)$.

Nitrogen adsorption and desorption measurements were carried out at $-196{ }^{\circ} \mathrm{C}$ using an ASAP 2020 (Micromeritics) porosimeter. Before the measurement, the samples were degassed $\left(1.33 \times 10^{-2} \mathrm{~Pa}\right)$ at $150^{\circ} \mathrm{C}$ for $4 \mathrm{~h}$. The specific surface areas were calculated using the Brunauer-Emmet-Teller (BET) method, and the pore size distributions were determined by the Barret-Joyner-Halenda (BJH) model, from the desorption branches.

Fourier transform infrared (FT-IR) spectra in transmission mode were analyzed on a Tensor 27 (Bruker) spectrometer with the aid of $\mathrm{KBr}$ pellets. Each spectrum was measured with a resolution of $4 \mathrm{~cm}^{-1}$ and recorded at room temperature.

X-ray photoelectron spectroscopy (XPS) measurements were carried out on a PHI 5000C (Perkin-Elmer) spectrometer recording in the constant energy mode $\left(\mathrm{Mg} K_{\alpha}\right.$ radiation as the excitation source).

UV-vis diffuse reflectance spectra (DRS) were recorded in a UV-3600 (Shimizu) spectrophotometer. The UV-vis spectra used $\mathrm{BaSO}_{4}$ as the standard reference.

Thermal gravimetric (TG) tests were performed on a TGA 7 (Perkin-Elmer) thermogravimetric analyzer. The specimens were heated, under a flow of air, from 50 to $800{ }^{\circ} \mathrm{C}$ with a ramping rate of $20^{\circ} \mathrm{C} \mathrm{min}-1$.

Transmission electron microscopy (TEM) images were obtained on a Tecnai G2 F20 S-TWIN microscope operated at 200 $\mathrm{kV}$. Energy dispersive X-ray spectra (EDS) and elemental mapping were performed on the equipped Oxford X-Max 80T detector.

\subsection{Catalytic evaluation}

The catalytic reactions were evaluated in a round-bottom flask. Benzene (1 mL, $11.2 \mathrm{mmol}$ ) and solvent ( $5 \mathrm{~mL}$ of acetonitrile and $1 \mathrm{~mL}$ of acetic acid) were mixed well, followed by the addition of the catalyst. After the temperature of the mixture reached $60{ }^{\circ} \mathrm{C}, 3 \mathrm{~mL}$ of $\mathrm{H}_{2} \mathrm{O}_{2}$ (a.q., $30 \mathrm{wt} \%$ ) were continuously fed into the flask through a peristaltic pump (the addition of $\mathrm{H}_{2} \mathrm{O}_{2}$ lasted for $\sim 30 \mathrm{~min}$ ). During the reaction, a small amount of reaction mixture $(<0.15 \mathrm{~mL})$ was periodically collected and centrifuged. The liquid phase was analyzed by gas chromatography using an SE-54 capillary column. The conversion (Conv.) of benzene and selectivity (Sel.) for phenol were calculated by means of an area-normalization method, and the detailed calculation equations were as follows: 


$$
\begin{gathered}
\text { Conv. }=\frac{n_{\text {phenol }}+n_{\text {benzoquinone }}}{n_{\text {benzene }}+n_{\text {phenol }}+n_{\text {benzoquinone }}} \\
\text { Sel. }=\frac{n_{\text {phenol }}}{n_{\text {phenol }}+n_{\text {benzoquinone }}}
\end{gathered}
$$

\section{Results and discussion}

\subsection{Catalyst characterization}

The textural properties of the $\mathrm{g}-\mathrm{C}_{3} \mathrm{~N}_{4}$ and Fe-g- $\mathrm{C}_{3} \mathrm{~N}_{4}$ materials were initially measured by $\mathrm{N}_{2}$ adsorption-desorption characterization. The g- $\mathrm{C}_{3} \mathrm{~N}_{4}$ presents a type-IV isothermal curve (Fig. 1), along with a $\mathrm{H} 3$ hysteretic loop in the range of $p / p_{0}=$ 0.8-0.99, suggesting that the bare sample contains mesoporous structures. Notwithstanding, the total pore volume as well as the surface area measured from g- $\mathrm{C}_{3} \mathrm{~N}_{4}$ are very low (Table 1). Comparatively, the incorporation of Fe into g- $\mathrm{C}_{3} \mathrm{~N}_{4}$ effectively improves the surface area and total pore volume. In the case of $10.0 \mathrm{Fe}-\mathrm{g}-\mathrm{C}_{3} \mathrm{~N}_{4}$, the pore volume and surface area are $0.25 \mathrm{~cm}^{3}$ $\mathrm{g}^{-1}$ and $56 \mathrm{~m}^{2} \mathrm{~g}^{-1}$, respectively. However, with further increases in the amount of $\mathrm{Fe}$, the textural parameters of $\mathrm{Fe}-\mathrm{g}-\mathrm{C}_{3} \mathrm{~N}_{4}$ decrease.

Fig. 2 presents the XRD profiles of the bulk g- $\mathrm{C}_{3} \mathrm{~N}_{4}$ and Fe-g- $\mathrm{C}_{3} \mathrm{~N}_{4}$ composites. The pure g- $\mathrm{C}_{3} \mathrm{~N}_{4}$ presents a sharp diffraction peak at $2 \theta=27.4^{\circ}(d=0.375 \mathrm{~nm})$. This peak is indexed as (002) planes, i.e. the interplanar stacking structure of graphitic material $[19,32]$. Furthermore, a small peak with weak intensity is found at $2 \theta=13.2^{\circ}(d=0.776 \mathrm{~nm})$, corresponding to an in-plane structural packing motif (i.e. hole-to-hole array of the nitride pores) [19]. As for the Fe-g- $\mathrm{C}_{3} \mathrm{~N}_{4}$ materials, the intensity of the (002) peaks becomes much weaker, while their (100) peaks seem to disappear. The comparison suggests that after incorporation of $\mathrm{Fe}$, the crystallinity of the graphitic structure of g- $\mathrm{C}_{3} \mathrm{~N}_{4}$ is drastically decreased. Moreover, the position of the (002) diffraction peaks of the Fe-g- $\mathrm{C}_{3} \mathrm{~N}_{4}$ composites moves toward higher values of $2 \theta$ (the inset of Fig. 2), indicating that the introduction of Fe probably results in the shrinkage

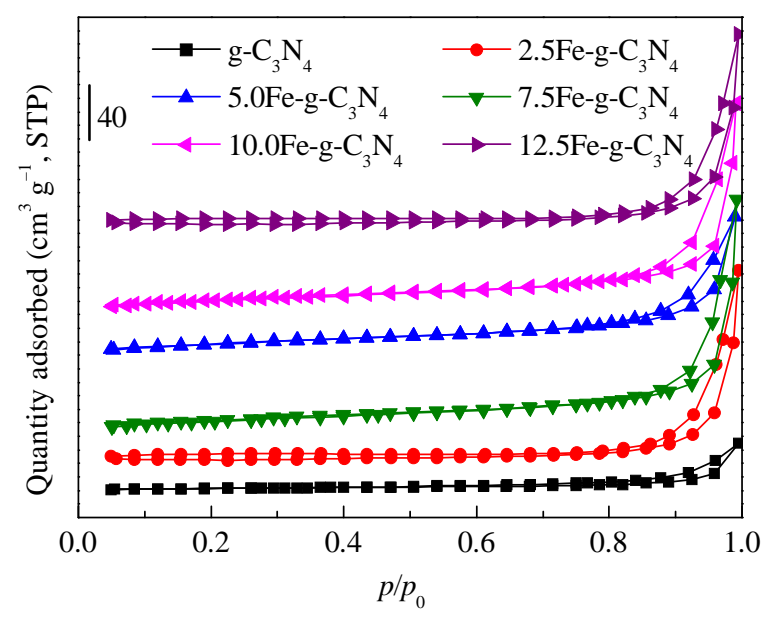

Fig. 1. $N_{2}$ adsorption-desorption isotherms of the g- $C_{3} N_{4}$ and Fe-g- $C_{3} N_{4}$ materials.
Table 1

Textural parameters of the g- $\mathrm{C}_{3} \mathrm{~N}_{4}$ and Fe-g- $\mathrm{C}_{3} \mathrm{~N}_{4}$ materials.

\begin{tabular}{lcc}
\hline Sample & $S_{\text {BET }}\left(\mathrm{m}^{2} \mathrm{~g}^{-1}\right)$ & Pore volume $\left(\mathrm{cm}^{3} \mathrm{~g}^{-1}\right)$ \\
\hline g- $\mathrm{C}_{3} \mathrm{~N}_{4}$ & 10 & 0.05 \\
$2.5 \mathrm{Fe}-\mathrm{g}-\mathrm{C}_{3} \mathrm{~N}_{4}$ & 8 & 0.22 \\
$5.0 \mathrm{Fe}-\mathrm{g}-\mathrm{C}_{3} \mathrm{~N}_{4}$ & 48 & 0.17 \\
$7.5 \mathrm{Fe}-\mathrm{g}-\mathrm{C}_{3} \mathrm{~N}_{4}$ & 49 & 0.27 \\
$10.0 \mathrm{Fe}-\mathrm{g}-\mathrm{C}_{3} \mathrm{~N}_{4}$ & 56 & 0.25 \\
$12.5 \mathrm{Fe}-\mathrm{g}-\mathrm{C}_{3} \mathrm{~N}_{4}$ & 18 & 0.22 \\
\hline
\end{tabular}

of the graphitic interlayers of g- $\mathrm{C}_{3} \mathrm{~N}_{4}$.

It is of interest to mention that we previously reported the fabrication of $\mathrm{MgO} / \mathrm{g}-\mathrm{C}_{3} \mathrm{~N}_{4}$ materials starting from $\mathrm{Mg}\left(\mathrm{NO}_{3}\right)_{2}$ and DCDA [33]. The synthetic route of these materials was very similar to this work. By contrast, the position of the primary (002) peak obtained in $\mathrm{MgO} / \mathrm{g}-\mathrm{C}_{3} \mathrm{~N}_{4}$ was much lower than that of the pure $\mathrm{g}-\mathrm{C}_{3} \mathrm{~N}_{4}$ sample. We surmise that the difference in terms of the $d$ spacing value of the graphitic interlayers lies in the precursor of the metal salts. In other words, during the pyrolysis of DCDA to $\mathrm{g}-\mathrm{C}_{3} \mathrm{~N}_{4}, \mathrm{Mg}\left(\mathrm{NO}_{3}\right)_{2}$ also underwent decomposition and released a large amount of gas, leading to the expansion of the graphitic layers. In comparison, in the case of Fe-g- $\mathrm{C}_{3} \mathrm{~N}_{4}$, although the reaction between $\mathrm{FeCl}_{3}$ and $\mathrm{g}-\mathrm{C}_{3} \mathrm{~N}_{4}$ for the formation of $\mathrm{g}-\mathrm{C}_{3} \mathrm{~N}_{4}$ would also generate gas (such as $\mathrm{HCl}$ ), the shrinkage and/or collapse of the graphitic layers of $g-\mathrm{C}_{3} \mathrm{~N}_{4}$ may occur dominantly, which might be responsible for the abovementioned decrease of crystallinity of $\mathrm{g}-\mathrm{C}_{3} \mathrm{~N}_{4}$ after the introduction of Fe.

The morphology of the materials was observed by TEM. The low-resolution images of 7.5Fe-g- $\mathrm{C}_{3} \mathrm{~N}_{4}$ (Fig. $3(\mathrm{~A})$ and $(\mathrm{C})$ ) reveal apparent worm-like structures. From these two TEM images, the mean size of most of such pores is much larger than $50 \mathrm{~nm}$. The high-resolution image (Fig. 3(B)) displays thin-layer morphology; however, no obvious particles have been detected in the images. Moreover, the EDS mapping images of $7.5 \mathrm{Fe}-\mathrm{g}-\mathrm{C}_{3} \mathrm{~N}_{4}$ verify that the carbon, nitrogen, and iron elements are well dispersed on the material. In contrast, the oxygen element shows irregular distribution on the surface of

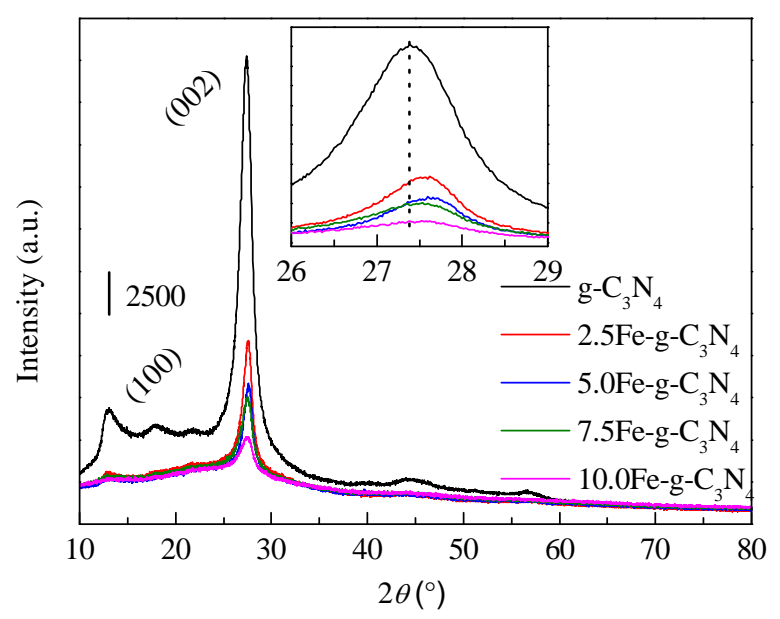

Fig. 2. XRD patterns of the $\mathrm{g}-\mathrm{C}_{3} \mathrm{~N}_{4}$ and Fe-g- $\mathrm{C}_{3} \mathrm{~N}_{4}$ materials. 

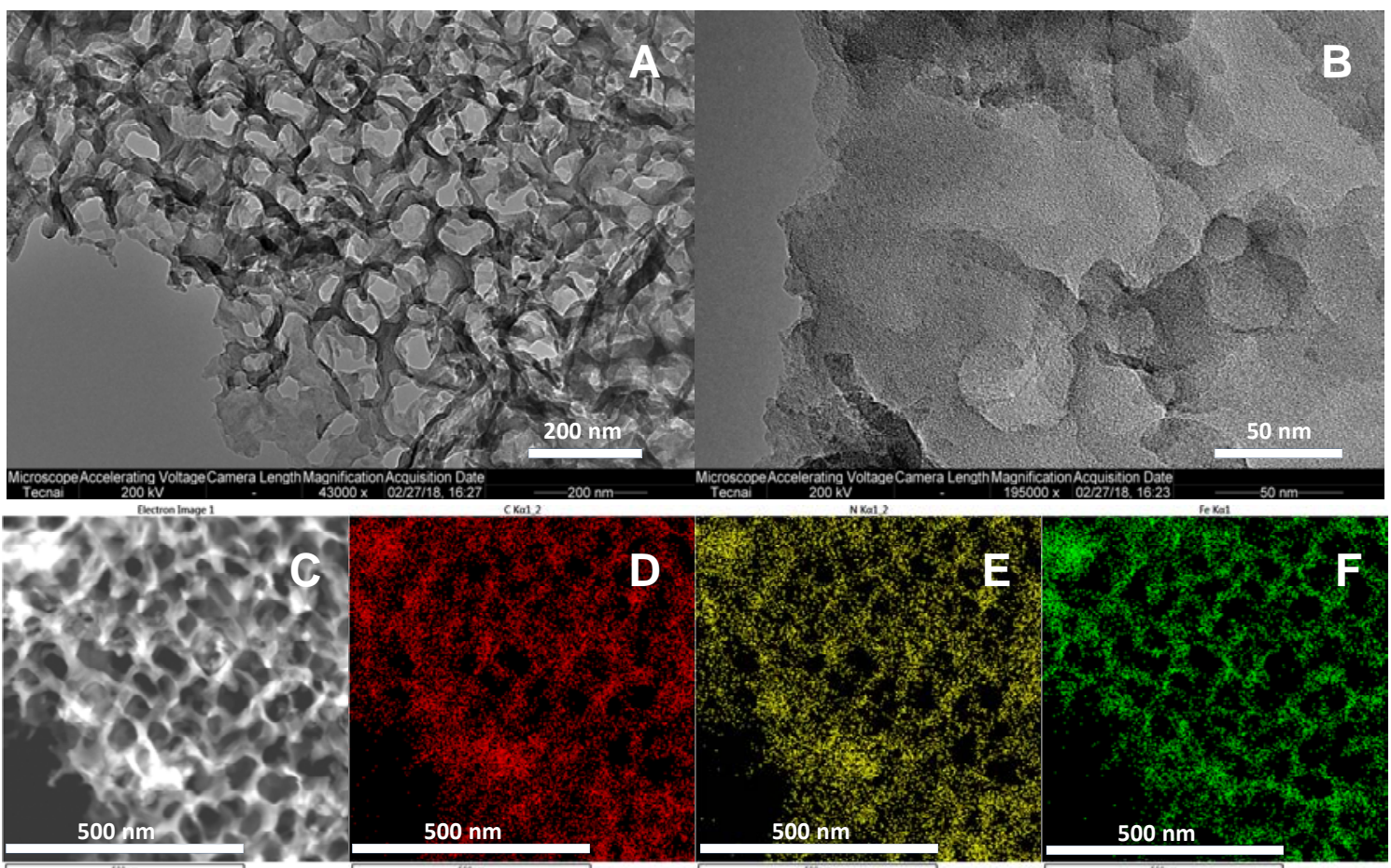

Fig. 3. TEM images (A-C) of 7.5Fe-g- $\mathrm{C}_{3} \mathrm{~N}_{4}$ and the corresponding EDS mapping images of the carbon (D), nitrogen (E), and iron (F) elements.

7.5Fe-g- $\mathrm{C}_{3} \mathrm{~N}_{4}$ (Fig. S1), excluding the formation of iron oxide on the Fe-g- $\mathrm{C}_{3} \mathrm{~N}_{4}$ materials.

The TG curves of various materials are illustrated in Fig. S2. The pure g- $\mathrm{C}_{3} \mathrm{~N}_{4}$ shows good thermal stability below $500{ }^{\circ} \mathrm{C}$ while undergoing significant weight loss in the range of $550-750{ }^{\circ} \mathrm{C}$, due to its decomposition. The introduction of $\mathrm{Fe}$ into g- $\mathrm{C}_{3} \mathrm{~N}_{4}$ obviously undermines the thermal stability, making the decomposition temperature much lower. According to the values of the residual weight obtained at $750{ }^{\circ} \mathrm{C}$ (the final solid is $\mathrm{Fe}_{2} \mathrm{O}_{3}$ ), the loading amount of $\mathrm{Fe}$ in the various Fe-g- $\mathrm{C}_{3} \mathrm{~N}_{4}$ samples can be estimated. As listed in Table S1, the content of acquired-Fe in $7.5 \mathrm{Fe}-\mathrm{g}-\mathrm{C}_{3} \mathrm{~N}_{4}$ is $\sim 1.0 \mathrm{mmol} \mathrm{g}_{\mathrm{catal}^{-1}}$, and the contents of $\mathrm{Fe}$ for the other materials correlate well with their

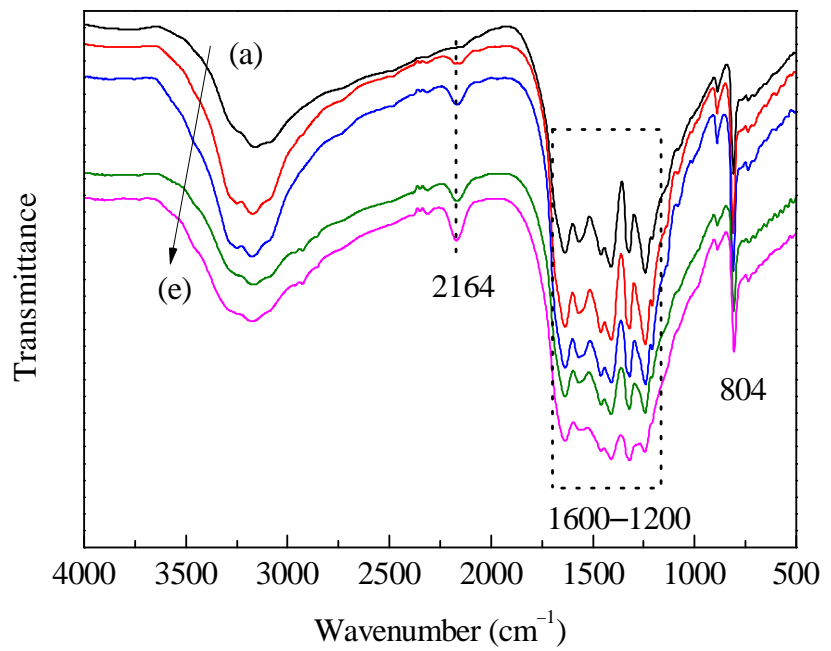

Fig. 4. FT-IR spectra of the $\mathrm{g}-\mathrm{C}_{3} \mathrm{~N}_{4}$ (a), $2.5 \mathrm{Fe}-\mathrm{g}-\mathrm{C}_{3} \mathrm{~N}_{4}$ (b), $5.0 \mathrm{Fe}-\mathrm{g}-\mathrm{C}_{3} \mathrm{~N}_{4}$ (c), 7.5Fe-g- $\mathrm{C}_{3} \mathrm{~N}_{4}(\mathrm{~d})$, and $10.0 \mathrm{Fe}-\mathrm{g}-\mathrm{C}_{3} \mathrm{~N}_{4}$ (e) materials. nominal loading amounts.

The chemical functionalities of the materials were analyzed by FT-IR. All the spectra exhibit three major band zones (Fig. 4). The broad bands centered at $\sim 3165 \mathrm{~cm}^{-1}$ are attributed to the uncondensed amino functionalities $\left(-\mathrm{NH}_{2}\right.$ and $\left.-\mathrm{NH}-\right)$ at the edges of the graphitic layers of $\mathrm{g}-\mathrm{C}_{3} \mathrm{~N}_{4}$ [34] and to the $\mathrm{O}-\mathrm{H}$ derived from the absorbed surface water. The multiple bands appearing from 1600 to $1200 \mathrm{~cm}^{-1}$ correspond to the stretching modes of the nitrogen heterocycles (i.e. triazine or tri-s-triazine) [32], while the high-intensity sharp peaks located at $804 \mathrm{~cm}^{-1}$ are assigned to the breathing mode of triazine-based sheets of $\mathrm{g}-\mathrm{C}_{3} \mathrm{~N}_{4}$. Compared with the spectrum of g- $\mathrm{C}_{3} \mathrm{~N}_{4}$, in the case of $\mathrm{Fe}-\mathrm{g}-\mathrm{C}_{3} \mathrm{~N}_{4}$ the intensity of the peaks associated with the $\mathrm{CN}$ heterocycles clearly decreases with the increment of Fe content. This phenomenon signifies that the tectonic units of tri-s-triazine of $\mathrm{g}-\mathrm{C}_{3} \mathrm{~N}_{4}$ were damaged, possibly due to the interaction between iron and the $\mathrm{N}$ species of g- $\mathrm{C}_{3} \mathrm{~N}_{4}$ [35]. Furthermore, a distinct peak emerges at $2164 \mathrm{~cm}^{-1}$ for each Fe-g- $\mathrm{C}_{3} \mathrm{~N}_{4}$, which, however, cannot be observed in the FT-IR spectrum of g- $\mathrm{C}_{3} \mathrm{~N}_{4}$. These unique transmission signals have also been found in the spectra of Fe- and Zn-doped g- $\mathrm{C}_{3} \mathrm{~N}_{4}$ materials previously reported by other groups [36,37], and were indexed as $\mathrm{C} \equiv \mathrm{N}$ bonds converted from $s p^{2}$-hybridized $\mathrm{C}-\mathrm{N}$ bonds, thus further verifying the steady interaction between Fe and $\mathrm{g}-\mathrm{C}_{3} \mathrm{~N}_{4}$, in the Fe-g- $\mathrm{C}_{3} \mathrm{~N}_{4}$ materials.

The XPS technique was further employed to probe the chemical bonding states on the surface of the materials, and the survey spectra are presented in Fig. S3. The spectrum of g- $\mathrm{C}_{3} \mathrm{~N}_{4}$ shows the signals of carbon and nitrogen, along with a minor peak assigned to the oxygen element (coming from the adsorbed water molecules). The molar ratio of $\mathrm{C} / \mathrm{N}$ is $\sim 0.71$, with higher nitrogen content than the theoretical value of the ideal 


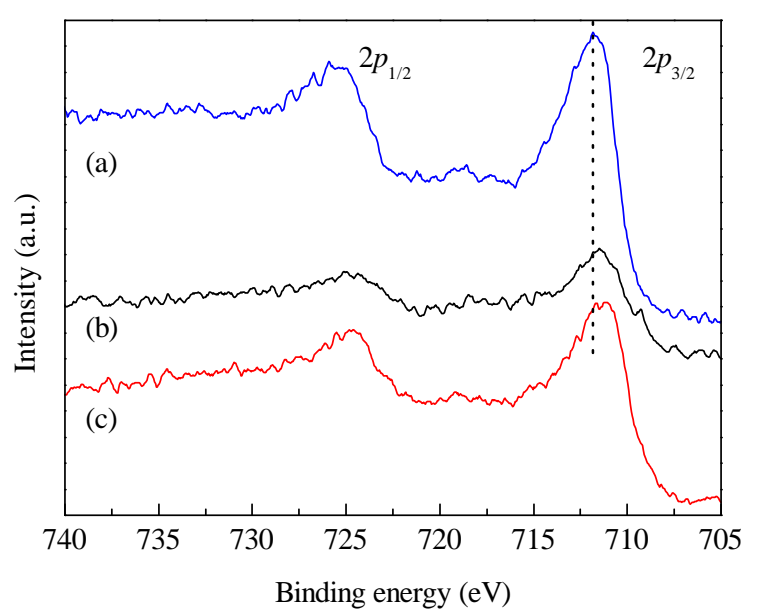

Fig. 5. Fe 2p XPS spectra of the $\mathrm{FeCl}_{3}$ (a), 2.5Fe-g- $\mathrm{C}_{3} \mathrm{~N}_{4}$ (b), and 7.5Fe-g- $\mathrm{C}_{3} \mathrm{~N}_{4}$ (c) materials.

g- $\mathrm{C}_{3} \mathrm{~N}_{4}$ (0.75). This difference is due to the existence of uncondensed terminal amino groups of $g-\mathrm{C}_{3} \mathrm{~N}_{4}[33,38]$, which are also revealed in the above FT-IR spectra. Besides those of the carbon, nitrogen, and oxygen elements, two peaks appear at $\sim 712$ and $201 \mathrm{eV}$ in the spectrum of each Fe-g- $\mathrm{C}_{3} \mathrm{~N}_{4}$ sample, which are indicative of $\mathrm{Fe} 2 p$ and $\mathrm{Cl} 2 p$, respectively. Furthermore, the peak intensity of oxygen shows remarkable enhancement with the increment of $\mathrm{Fe}$ in the $\mathrm{g}-\mathrm{C}_{3} \mathrm{~N}_{4}$ sample. This behavior should be attributed to the partial hydrolysis of $\mathrm{FeCl}_{3}$ on the surface of g- $\mathrm{C}_{3} \mathrm{~N}_{4}$, which is also observed in the spectrum of the pure $\mathrm{FeCl}_{3}$ compound.

The fine XPS spectra of $\mathrm{Fe} 2 p$ for the Fe-g- $\mathrm{C}_{3} \mathrm{~N}_{4}$ materials, as well as for $\mathrm{FeCl}_{3}$, are given in Fig. 5. The spectrum of $\mathrm{FeCl}_{3}$ exhibits two binding peaks centered at 725.1 and $712.0 \mathrm{eV}$, ascribed to the signals of the $2 p_{1 / 2}$ and $2 p_{3 / 2}$ orbits, respectively. By comparison, the peaks acquired in the Fe-g- $\mathrm{C}_{3} \mathrm{~N}_{4}$ samples shift to lower binding energies. Interestingly, the average peak position $(711.4 \mathrm{eV})$ of the $2 p_{3 / 2}$ orbit of Fe-g- $\mathrm{C}_{3} \mathrm{~N}_{4}$ resembles the value reported for Fe(III) porphyrin. In that compound, the Fe center is coordinated by N4-tetradentate ligands and a chlo- ride anion [39]. As proposed by Wang et al. [40], g- $\mathrm{C}_{3} \mathrm{~N}_{4}$ built up by tri-s-triazine rings as tectonic units contains abundant "nitrogen pots" (also called "nitrogen holes"), very similarly to other nitrogen-enriched $\pi$-conjugated macrocyclic compounds, such as porphyrin and phthalocyanine. Accordingly, the $\mathrm{g}-\mathrm{C}_{3} \mathrm{~N}_{4}$ material possessing this similar nitrogen pots has an innate ability to coordinate or anchor transition-metal species (e.g. Fe and $\mathrm{Zn}$ ). Therefore, it is reasonable to surmise that there is a potential interaction between $\mathrm{Fe}$ and the nitrogen species of g- $\mathrm{C}_{3} \mathrm{~N}_{4}[23,40]$. More specifically, the Fe cations are anchored by nitrogen-rich $\mathrm{g}-\mathrm{C}_{3} \mathrm{~N}_{4}$ through $\mathrm{Fe}-\mathrm{N}$ bonds. However, given the $\mathrm{Cl}$ signals revealed in Fig. S3, a certain amount of Fe species ought to exist as $\mathrm{FeCl}_{3}$.

In order to further analyze the chemical bonding information of the $\mathrm{g}-\mathrm{C}_{3} \mathrm{~N}_{4}$ and Fe-g- $\mathrm{C}_{3} \mathrm{~N}_{4}$ materials, deconvolution of the $\mathrm{N} 2 p$ signals of the g- $\mathrm{C}_{3} \mathrm{~N}_{4}, 2.5 \mathrm{Fe}-\mathrm{g}-\mathrm{C}_{3} \mathrm{~N}_{4}$, and 7.5Fe-g- $\mathrm{C}_{3} \mathrm{~N}_{4}$ samples was performed (Fig. 6). Each spectrum could be separated into three independent peaks, i.e. three types of $\mathrm{N}$ atoms. The dominance of the $\mathrm{N} 1 \mathrm{~s}$ spectrum with the lowest binding energy (398.8 $\pm 0.2 \mathrm{eV}$ ) is indexed as the $s p^{2}$-hybridized nitrogen $\left(\mathrm{N}_{\mathrm{a}}\right)$, existing as $\mathrm{C}-\mathrm{N}=\mathrm{C}$ groups in the tri-s-triazine rings. The peak located at $399.8 \pm 0.2 \mathrm{eV}$ is associated with the $\mathrm{sp}^{2}$-hybridized nitrogen atoms $\left(\mathrm{N}_{\mathrm{b}}, \mathrm{C}-\mathrm{NH}-\mathrm{C}\right.$ and $\left.\mathrm{C}-\mathrm{N}(-\mathrm{C})-\mathrm{C}\right)$ which bridge two or three tri-s-triazine units. The peak with the highest binding energy ( $401.2 \pm 0.2 \mathrm{eV}$ ) corresponds to the uncondensed terminal amino groups $\left(\mathrm{N}_{\mathrm{c}},-\mathrm{NH}_{2}\right.$ and $\left.-\mathrm{NH}-\right)$ which have been revealed in the above FT-IR spectra (Fig. 4). The detailed molar distributions of the various nitrogen species for the three samples are summarized in Table S2. The percentages of $\mathrm{N}_{\mathrm{a}}$ and $\mathrm{N}_{\mathrm{b}}$ atoms of $\mathrm{g}-\mathrm{C}_{3} \mathrm{~N}_{4}$ are $69.0 \%$ and $22.5 \%$, respectively. The incorporation of $\mathrm{FeCl}_{3}$ leads to the variation of the distribution of nitrogen species. That is, the percentages of the $\mathrm{N}_{\mathrm{a}}$ species decrease while those of the $\mathrm{N}_{\mathrm{b}}$ species increase drastically from the g- $\mathrm{C}_{3} \mathrm{~N}_{4}$ to the Fe-g- $\mathrm{C}_{3} \mathrm{~N}_{4}$ samples. Such a change has been observed for $\mathrm{Zn}$-doped g- $\mathrm{C}_{3} \mathrm{~N}_{4}$ materials reported by our [28] and other groups [41]. The increase of the bridging nitrogen species is probably originated from the reaction between $\mathrm{FeCl}_{3}$ and the $\mathrm{N}_{\mathrm{a}}$ atoms in the conjugated
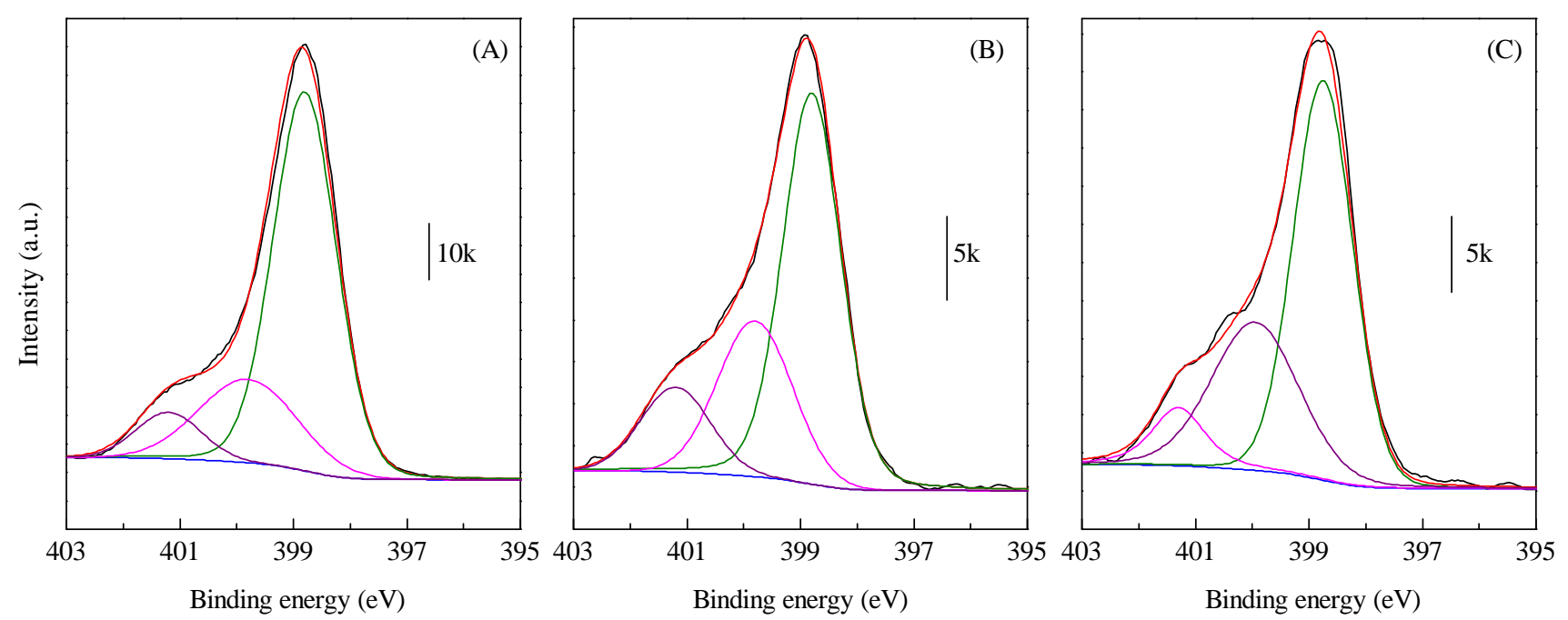

Fig. 6. $\mathrm{N} 1 s$ XPS spectra of the g- $\mathrm{C}_{3} \mathrm{~N}_{4}(\mathrm{~A}), 2.5 \mathrm{Fe}-\mathrm{g}-\mathrm{C}_{3} \mathrm{~N}_{4}$ (B), and 7.5Fe-g- $\mathrm{C}_{3} \mathrm{~N}_{4}(\mathrm{C})$ materials. 


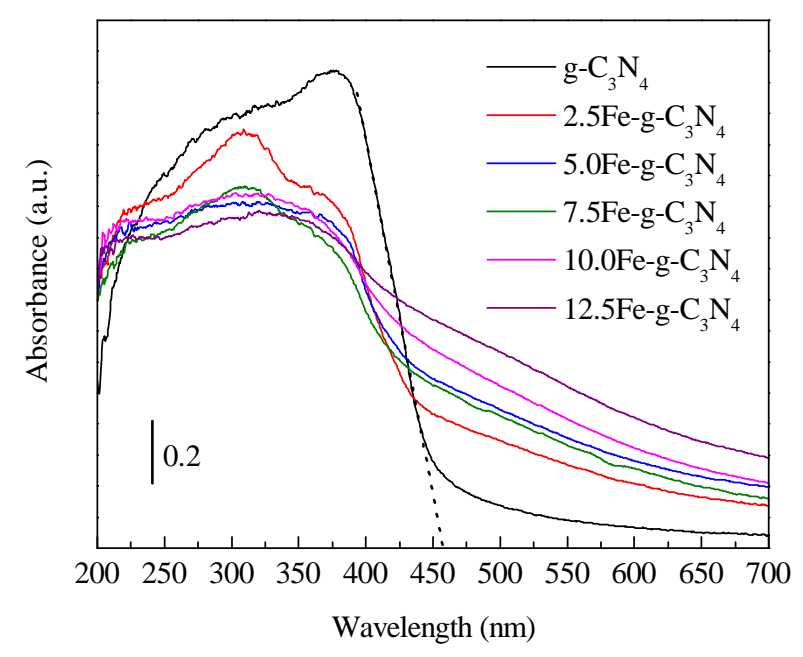

Fig. 7. UV-vis spectra of the g- $\mathrm{C}_{3} \mathrm{~N}_{4}, 2.5 \mathrm{Fe}-\mathrm{g}-\mathrm{C}_{3} \mathrm{~N}_{4}, 5.0 \mathrm{Fe}-\mathrm{g}-\mathrm{C}_{3} \mathrm{~N}_{4}$, 7.5Fe-g- $\mathrm{C}_{3} \mathrm{~N}_{4}, 10.0 \mathrm{Fe}-\mathrm{g}-\mathrm{C}_{3} \mathrm{~N}_{4}$, and $12.5 \mathrm{Fe}-\mathrm{g}-\mathrm{C}_{3} \mathrm{~N}_{4}$ samples.

tri-s-triazine rings of g- $\mathrm{C}_{3} \mathrm{~N}_{4}$. Such a reaction directly results in the partial breakage of the tri-s-triazine motifs (also as observed in the above FT-IR spectra) and the formation of more bridging $\mathrm{N}_{\mathrm{b}}$ species. On the other hand, a certain amount of $\mathrm{Fe}$ species is included by adjacent nitrogen species.

UV-vis diffuse reflectance spectra of the $\mathrm{g}-\mathrm{C}_{3} \mathrm{~N}_{4}$ and Fe-g- $\mathrm{C}_{3} \mathrm{~N}_{4}$ specimens are displayed in Fig. 7. The spectrum of the pristine g- $\mathrm{C}_{3} \mathrm{~N}_{4}$ shows a major optical absorption with a cutting edge at $\sim 457 \mathrm{~nm}$, corresponding to a band gap of $\sim 2.7$ $\mathrm{eV}$. The absorption is derived from the band gap between HOMO and LUMO in the polymeric melon units of $\mathrm{g}-\mathrm{C}_{3} \mathrm{~N}_{4}$ [42]. A remarkable red shift is detected for each Fe-g- $\mathrm{C}_{3} \mathrm{~N}_{4}$ material. More specifically, with the increment of Fe content, the band gap is moved progressively towards longer wavelengths. The red shift results from the variation of the electronic structure of g- $\mathrm{C}_{3} \mathrm{~N}_{4}$, arising from the incorporation of $\mathrm{Fe}$ into the skeleton of g- $\mathrm{C}_{3} \mathrm{~N}_{4}$, i.e. $d-p$ repulsion between Fe $3 d$ and $\mathrm{N} 2 p$ orbits [35]. Indeed, similar results have also been observed in other $\mathrm{g}-\mathrm{C}_{3} \mathrm{~N}_{4}$ materials doped by Fe [35,43], Zn [28,40,44], and other transition metals [23].

\section{Table 2}

Catalytic results of the hydroxylation of benzene to phenol under various materials a

\begin{tabular}{lcccc}
\hline Entry & Catalyst & Conv. (\%) & Sel. (\%) & $\begin{array}{c}\text { Catalytic productivity } \\
\left(\mathrm{g} \mathrm{h}^{-1} \mathrm{gcat}^{-1}\right)\end{array}$ \\
\hline $1{ }^{\mathrm{b}}$ & - & - & - & - \\
2 & ${\mathrm{~g}-\mathrm{C}_{3} \mathrm{~N}_{4}}^{\mathrm{FeCl}}{ }_{3}$ & - & - & - \\
3 & $\mathrm{FeCl}_{3}$ & 12.2 & $>99$ & 1.29 \\
4 & $2.5 \mathrm{Fe}-\mathrm{g}-\mathrm{C}_{3} \mathrm{~N}_{4}$ & 6.8 & $>99$ & 0.72 \\
5 & $5.0 \mathrm{Fe}-\mathrm{g}-\mathrm{C}_{3} \mathrm{~N}_{4}$ & 13.7 & $>99$ & 1.44 \\
6 & $7.5 \mathrm{Fe}-\mathrm{g}-\mathrm{C}_{3} \mathrm{~N}_{4}$ & 17.5 & $>99$ & 1.84 \\
7 & $10.0 \mathrm{Fe}-\mathrm{g}-\mathrm{C}_{3} \mathrm{~N}_{4}$ & 13.9 & $>99$ & 1.46 \\
8 & $12.5 \mathrm{Fe}-\mathrm{g}-\mathrm{C}_{3} \mathrm{~N}_{4}$ & 10.7 & $>99$ & 1.13 \\
\hline
\end{tabular}

a Reaction conditions: $11.2 \mathrm{mmol}$ of benzene, $3 \mathrm{~mL}$ of aqueous $\mathrm{H}_{2} \mathrm{O}_{2}$ solution (30 wt\%), $1 \mathrm{~mL}$ of acetic acid and $5 \mathrm{~mL}$ of acetonitrile as solvents, $50 \mathrm{mg}$ of the catalyst, $T=60^{\circ} \mathrm{C}$, and $t=2 \mathrm{~h}$.

b Without any catalyst.

c Determined by the mass of phenol per gram of overall catalyst per hour.

\subsection{Catalyst activity}

Initially, a blank test of the hydroxylation of benzene without any catalyst was carried out, and no benzene was converted (Table 2). Likewise, in the presence of pure g- $\mathrm{C}_{3} \mathrm{~N}_{4}$, no phenol or other product has been detected. Using $\mathrm{FeCl}_{3}$ instead, the benzene conversion is $12.2 \%$ and the selectivity to the target phenol is higher than $99 \%$. Obviously, as a Lewis base, $\mathrm{FeCl}_{3}$ can promote the reaction. Despite its good catalytic activity, $\mathrm{FeCl}_{3}$ itself is dissolved in the reaction liquid. In a homogeneously catalytic reaction, it is relatively difficult to separate the catalyst from the liquid phase and then recycle it. Fe-g- $\mathrm{C}_{3} \mathrm{~N}_{4}$ catalysts show apparent catalytic activity in the hydroxylation reactions, and with an increase of the Fe content, the benzene conversion is remarkably improved. Furthermore, no by-product (e.g. benzoquinone) was detected. Among the Fe-g- $\mathrm{C}_{3} \mathrm{~N}_{4}$ materials, 7.5Fe-g- $\mathrm{C}_{3} \mathrm{~N}_{4}$ demonstrated the highest catalytic activity, affording a maximum yield of phenol in $2 \mathrm{~h}$ under $60^{\circ} \mathrm{C}$.

Fig. 8 shows the influence of the reaction conditions on the results of the catalytic hydroxylation of benzene. At a low reaction temperature of $50{ }^{\circ} \mathrm{C}$ (Fig. 8(A)), the benzene conversion obtained at $2 \mathrm{~h}$ of reaction time is $\sim 8.5 \%$ and the selectivity to phenol is higher than $99 \%$. As the reaction temperature is elevated, the conversion is improved and reaches its maximum at $60{ }^{\circ} \mathrm{C}$. However, further raising of temperature would lead to a gradual decline of catalytic activity, which should be due to the rapid decomposition of $\mathrm{H}_{2} \mathrm{O}_{2}$ at higher reaction temperature. Fig. 8(B) plots the results of the catalytic hydroxylation of benzene during $3 \mathrm{~h}$. It can be found that the conversion increases continuously yet levels off after $2 \mathrm{~h}$. Moreover, the selectivity to phenol collected across the reaction process is above $99 \%$.

In addition to the reaction temperature and time, the dependence of catalytic performance on catalyst amount and content of $\mathrm{H}_{2} \mathrm{O}_{2}$ was further investigated using $7.5 \mathrm{Fe}-\mathrm{g}-\mathrm{C}_{3} \mathrm{~N}_{4}$ as a catalyst. As described in Fig. S4, in the presence of only $25 \mathrm{mg}$ of the catalyst, the phenol yield reaches $\sim 11.0 \%$. Further increasing the amount of the catalyst could produce much higher
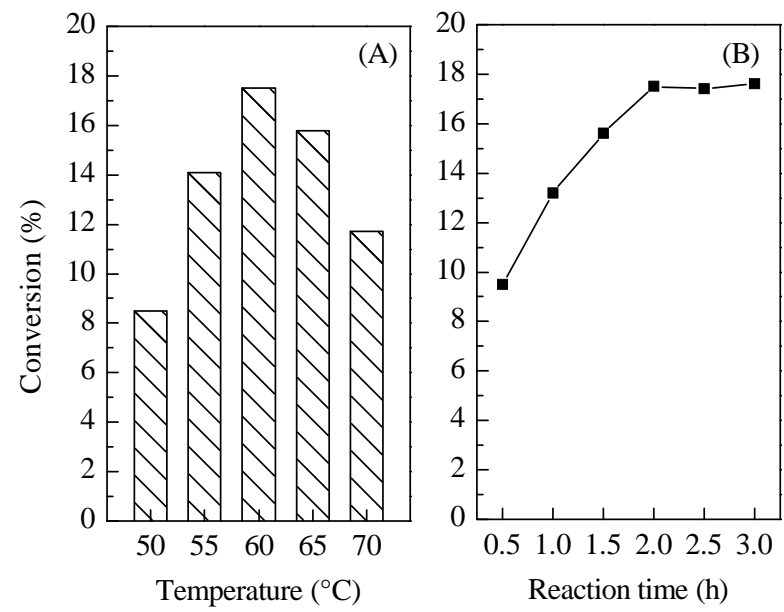

Fig. 8. Influence of temperature (A) and time (B) on the catalytic performance of 7.5Fe-g- $\mathrm{C}_{3} \mathrm{~N}_{4}$. Reaction conditions: benzene $1.0 \mathrm{~mL}, \mathrm{H}_{2} \mathrm{O}_{2}$ $3.0 \mathrm{~mL}$, solvent $6.0 \mathrm{~mL}$, catalyst $50 \mathrm{mg}, 2 \mathrm{~h}(\mathrm{~A}), 60^{\circ} \mathrm{C}(\mathrm{B})$. 
yields of phenol. Whereas, the use of an excessive amount of the catalyst depresses the catalytic productivity. One possible reason for this behavior is the decomposition of $\mathrm{H}_{2} \mathrm{O}_{2}$. Similar phenomena have been previously detected in the same reactions catalyzed by vanadium-doped $\mathrm{g}-\mathrm{C}_{3} \mathrm{~N}_{4}$ [4] and polyoxometalate [6] materials. Furthermore, in the catalytic reactions using various amounts of benzene, the highest phenol yield was obtained in the presence of $1.0 \mathrm{~mL}$ of benzene (Table S3).

To examine the reproducibility of the Fe-g- $\mathrm{C}_{3} \mathrm{~N}_{4}$ catalysts, we used $7.5 \mathrm{Fe}-\mathrm{g}-\mathrm{C}_{3} \mathrm{~N}_{4}$ as a representative catalyst and evaluated its catalytic performance in consecutive runs. After each test, the catalyst was immediately filtrated, washed with ethanol, and used for the subsequent evaluation. As revealed in Fig. 9, during the five consecutive catalytic runs, the phenol yields are $\sim 17 \%$, without any significant decline. Like $7.5 \mathrm{Fe}-\mathrm{g}-\mathrm{C}_{3} \mathrm{~N}_{4}$, the $5.0 \mathrm{Fe}-\mathrm{g}-\mathrm{C}_{3} \mathrm{~N}_{4}$ sample also shows stable catalytic activity during its recycling tests (Fig. S5), suggesting that the Fe-g- $\mathrm{C}_{3} \mathrm{~N}_{4}$ catalysts have good catalytic reproducibility.

As noted above, due to its innate capacity to activate benzene molecules, g- $\mathrm{C}_{3} \mathrm{~N}_{4}$ and the g- $\mathrm{C}_{3} \mathrm{~N}_{4}$-based materials have been recently employed as catalyst supports for many hydroxylation reactions of benzene to phenol. The catalytic performance of $7.5 \mathrm{Fe}-\mathrm{g}-\mathrm{C}_{3} \mathrm{~N}_{4}$ in this work is compared with those obtained over other $\mathrm{V}$ - and Fe-containing g- $\mathrm{C}_{3} \mathrm{~N}_{4}$ catalysts, which are summarized in Table 3. It is noted that all the entries are collected from papers published in the past five years. Actually, the reaction conditions including temperature, time, and feeding volume of benzene for each entry are very similar with others. In the case of $\mathrm{V}$-containing $\mathrm{g}-\mathrm{C}_{3} \mathrm{~N}_{4}$, the highest specific productivity $\left(1.57 \mathrm{~g} \mathrm{~h}^{-1} \mathrm{gcat}^{-1}\right.$ ) is offered by $\mathrm{V} / \mathrm{mp}-\mathrm{C}_{3} \mathrm{~N}_{4}$ (entry 3 ); although for this outstanding activity, the catalyst support (as well as that of entry 5) is mesoporous $\mathrm{g}-\mathrm{C}_{3} \mathrm{~N}_{4}$, which was fabricated by a complicated hard-templating method. As for Fe-containing g- $\mathrm{C}_{3} \mathrm{~N}_{4}$, entry 5 shows the highest yield of phenol (21.6\%); however, the reaction proceeded under light-assisted conditions $(\lambda>420 \mathrm{~nm})$. It is of interest to further compare the catalytic results of entries 6 and 7. In fact, both of these catalysts are prepared using $\mathrm{FeCl}_{3}$ as a precursor of Fe. We surmise that the significant difference in their catalytic activity might be due to the choice of the precursor of $\mathrm{g}-\mathrm{C}_{3} \mathrm{~N}_{4}$. The former uses urea as a starting material for $\mathrm{g}-\mathrm{C}_{3} \mathrm{~N}_{4}$ while the latter is synthesized based on DCDA. Compared with DCDA, the transformation of urea to the final g- $\mathrm{C}_{3} \mathrm{~N}_{4}$ would release much more gas

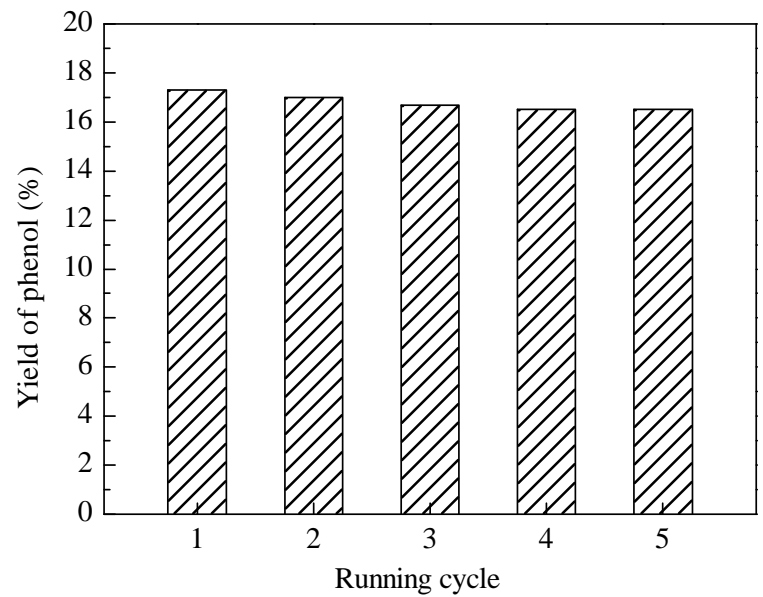

Fig. 9. Catalytic performances of 7.5Fe-g- $\mathrm{C}_{3} \mathrm{~N}_{4}$ during four consecutive runs. Reaction conditions: benzene $1.0 \mathrm{~mL}, \mathrm{H}_{2} \mathrm{O}_{2} 3.0 \mathrm{~mL}$, solvent $6.0 \mathrm{~mL}$, catalyst $50 \mathrm{mg}, 2 \mathrm{~h}, 60^{\circ} \mathrm{C}$.

due to the more drastic self-decomposition of urea, resulting in abundant incompletely condensed tri-s-triazine units with a low degree of polymerization [38,47]. Consequently, less Fe species could not be anchored and were further dispersed by g- $\mathrm{C}_{3} \mathrm{~N}_{4}$, in the case of entry 6 . In contrast, $7.5 \mathrm{Fe}-\mathrm{g}-\mathrm{C}_{3} \mathrm{~N}_{4}$ in this work exhibits superior catalytic productivity of phenol. Additionally, such Fe-g- $\mathrm{C}_{3} \mathrm{~N}_{4}$ materials could be easily and rapidly prepared.

\section{Conclusions}

In summary, Fe-containing g- $\mathrm{C}_{3} \mathrm{~N}_{4}$ materials have been synthesized by a rapid and simple approach. The graphitic structures of $\mathrm{g}-\mathrm{C}_{3} \mathrm{~N}_{4}$ have remained after the introduction of $\mathrm{Fe}$, and the synthesized Fe-g- $\mathrm{C}_{3} \mathrm{~N}_{4}$ materials possess surface areas of 8-56 $\mathrm{m}^{2} \mathrm{~g}^{-1}$. The Fe cations are anchored by nitrogen-abundant g- $\mathrm{C}_{3} \mathrm{~N}_{4}$ via $\mathrm{Fe}-\mathrm{N}$ bonds, with a minor charge balanced by chloride anions. In the hydroxylation of benzene in the presence of $\mathrm{H}_{2} \mathrm{O}_{2}$, Fe-g- $\mathrm{C}_{3} \mathrm{~N}_{4}$ samples as heterogeneous catalysts, show much higher catalytic activity than the pure g- $\mathrm{C}_{3} \mathrm{~N}_{4}$. Under optimized reaction conditions, the maximum yield of phenol is up to $17.5 \%$ at $60{ }^{\circ} \mathrm{C}$. Compared with other Fe- and vanadia- containing g- $\mathrm{C}_{3} \mathrm{~N}_{4}$ materials, Fe-g- $\mathrm{C}_{3} \mathrm{~N}_{4}$ features more facile preparation along with higher catalytic productivity of phenol.

Table 3

Comparison of the hydroxylation reactions of benzene catalyzed by various $\mathrm{V}$ - and Fe-containing g- $\mathrm{C}_{3} \mathrm{~N}_{4}$ catalysts.

\begin{tabular}{|c|c|c|c|c|c|c|c|c|}
\hline Entry & Catalyst & $\begin{array}{c}\text { Benzene } \\
(\mathrm{mL})\end{array}$ & $\begin{array}{l}\mathrm{H}_{2} \mathrm{O}_{2} \\
(\mathrm{~mL})\end{array}$ & $\begin{array}{l}\text { Catalyst } \\
\text { (mg) }\end{array}$ & $\begin{array}{c}T \\
\left({ }^{\circ} \mathrm{C}\right) \\
\end{array}$ & $\begin{array}{c}t \\
(\mathrm{~h})\end{array}$ & $\begin{array}{l}\text { Yield } \\
(\%)\end{array}$ & $\begin{array}{c}\text { Catalytic productivity a } \\
\left(\mathrm{g} \mathrm{h}^{-1} \mathrm{~g}_{\text {cat }}{ }^{-1}\right)\end{array}$ \\
\hline 1 & $\mathrm{~V} / \mathrm{g}-\mathrm{C}_{3} \mathrm{~N}_{4}[45]$ & 1.0 & 3.5 & 40 & 70 & 4 & 17.8 & 1.16 \\
\hline 2 & $0.4 \mathrm{~V}-\mathrm{g}-\mathrm{C}_{3} \mathrm{~N}_{4}[4]$ & 1.0 & 3.0 & 60 & 60 & 6 & 17.7 & 0.52 \\
\hline 3 & $\mathrm{~V} / \mathrm{mp}-\mathrm{C}_{3} \mathrm{~N}_{4}{ }^{\mathrm{b}}[46]$ & 1.5 & 3.0 & 60 & 60 & 3 & 17.9 & 1.57 \\
\hline 4 & VO-peg- $\mathrm{C}_{3} \mathrm{~N}_{4}{ }^{\mathrm{c}}[29]$ & 1.0 & 3.0 & 75 & 60 & 4 & 11.7 & 0.40 \\
\hline 5 & $10 \mathrm{FeCl}_{3} / \mathrm{mpg} \mathrm{C}_{3} \mathrm{~N}_{4}{ }^{\mathrm{b}}[30]$ & 0.4 & 0.25 & 25 & 60 & 4 & 21.6 & 0.91 \\
\hline 6 & Fe-g- $\mathrm{C}_{3} \mathrm{~N}_{4}[4]$ & 1.0 & 3.0 & 48 & 60 & 6 & 2.3 & 0.08 \\
\hline 7 & $7.5 \mathrm{Fe}-\mathrm{g}-\mathrm{C}_{3} \mathrm{~N}_{4}$ & 1.0 & 3.0 & 50 & 60 & 2 & 17.5 & 1.84 \\
\hline
\end{tabular}

a Determined according to the mass of obtained phenol per gram of overall catalyst per hour.

b Supported on mesoporous g- $\mathrm{C}_{3} \mathrm{~N}_{4}$ materials.

c Supported on exfoliated g- $\mathrm{C}_{3} \mathrm{~N}_{4}$ nanosheets. 


\section{Acknowledgments}

The authors thank Dr. Songhai Xie of Department of Chemistry, Fudan University for his very kind help in TEM characterization.

\section{References}

[1] Y. J. Zhu, Y. L. Dong, L. N. Zhao, F. L. Yuan, J. Mol. Catal. A, 2010, 315, 205-212.

[2] H. F. Wang, L. P. Fang, Y. F. Yang, L. Zhang, Y. J. Wang, Catal. Sci. Technol., 2016, 6, 8005-8015.

[3] J. H. Yang, G. Sun, Y. J. Gao, H. B. Zhao, P. Tang, J. Tan, A. H. Lu, D. Ma, Energy Environ. Sci., 2013, 6, 793-798.

[4] G. P. Ding, W. T. Wang, T. Jiang, B. X. Han, H. L. Fan, G. Y. Yang, ChemCatChem, 2013, 5, 192-200.

[5] Z. Y. Long, Y. Zhou, G. J. Chen, W. L. Ge, J. Wang, Sci. Rep., 2014, 4, 3651.

[6] P. P. Zhao, J. Wang, G. J. Chen, Y. Zhou, J. Huang, Catal. Sci. Technol,, 2013, 3, 1394-1404.

[7] P. Borah, X. Ma, K. T. Nguyen, Y. L. Zhao, Angew. Chem. Int. Ed., 2012, 51, 7756-7761.

[8] J. Xu, Q. Jiang, T. Chen, F. Wu, Y. X. Li, Catal. Sci. Technol,, 2015, 5, 1504-1513.

[9] P. Borah, A. Datta, K. T. Nguyen, Y. Zhao, Green Chem., 2015, 18, 397-401.

[10] T. Jiang, W. T. Wang, B. X. Han, New J. Chem., 2013, 37, 1654-1664.

[11] X. J. Ye, Y. J. Cui, X. Q. Qiu, X. C. Wang, Appl. Catal. B, 2014, 152-153, 383-389.

[12] D. Bianchi, L. Balducci, R. Bortolo, R. Daloisio, M. Ricci, G. Spano, R. Tassinari, C. Tonini, R. Ungarelli, Adv. Synth. Catal., 2007, 349, 979-986.

[13] Y. W. Chen, Y. H. Lu, Ind. Eng. Chem. Res., 1999, 38, 1893-1903.

[14] Y. T. Gong, M. M. Li, H. R. Li, Y. Wang, Green Chem., 2015, 17, 715-736.

[15] J. J. Zhu, P. Xiao, H. L. Li, S. A. C. Carabineiro, ACS Appl. Mater. Interfaces, 2014, 6, 16449-16465.

[16] Y. Wang, X. C. Wang, M. Antonietti, Angew. Chem. Int. Ed., 2012, 51, 68-89.

[17] P. F. Zhang, J. Deng, J. Y. Mao, H. R. Li, Y. Wang, Chin. J. Catal., 2015, $36,1580-1586$.

[18] F. Goettmann, A. Fischer, M. Antonietti, A. Thomas, Chem. Commun., 2006, 4530-4532.
[19] F. Goettmann, A. Fischer, M. Antonietti, A. Thomas, Angew. Chem. Int. Ed., 2006, 45, 4467-4471.

[20] J. Xu, H. T. Wu, X. Wang, B. Xue, Y. X. Li, Y. Cao, Phys. Chem. Chem. Phys., 2013, 15, 4510-4517.

[21] M. B. Ansari, B. H. Min, Y. H. Mo, S. E. Park, Green Chem., 2011, 13, 1416-1421.

[22] S. Verma, R. B. N. Baig, M. N. Nadagouda, R. S. Varma, ACS Sustain. Chem. Eng., 2016, 4, 2333-2336.

[23] Z. X. Ding, X. F. Chen, M. Antonietti, X. C. Wang, ChemSusChem, 2011, 4, 274-281.

[24] J. Xu, Q. Jiang, J. K. Shang, Y. Wang, Y. X. Li, RSC Adv,, 2015, 5, 92526-92533.

[25] X. F. Chen, Y. S. Jun, K. Takanabe, K. Maeda, K. Domen, X. Z. Fu, M. Antonietti, X. C. Wang, Chem. Mater., 2009, 21, 4093-4095.

[26] M. B. Ansari, H. L. Jin, M. N. Parvin, S. E. Park, Catal. Today, 2012, 185, 211-216.

[27] Y. Wang, X. C. Wang, M. Antonietti, Y. J. Zhang, ChemSusChem, 2010, 3, 435-439.

[28] J. Xu, K. Z. Long, Y. Wang, B. Xue, Y. X. Li, Appl. Catal. A, 2015, 496, $1-8$.

[29] J. Xu, Y. Chen, Y. Hong, H. Zheng, D. Ma, B. Xue, Y. X. Li, Appl. Catal. A, 2018, 549, 31-39.

[30] P. F. Zhang, Y. T. Gong, H. R. Li, Z. R. Chen, Y. Wang, RSC Adv., 2013, 3, 5121-5126.

[31] V. R. Choudhary, S. K. Jana, J. Mol. Catal. A, 2002, 180, 267-276.

[32] M. J. Bojdys, J. O. Müller, M. Antonietti, A. Thomas, Chem. Eur. J., 2008, 14, 8177-8182.

[33] J. Xu, Y. Chen, D. Ma, J. K. Shang, Y. X. Li, Catal. Commun., 2017, 95, 72-76.

[34] Q. Su, J. Sun, J. Q. Wang, Z. F. Yang, W. G. Cheng, S. J. Zhang, Catal. Sci. Technol, 2014, 4, 1556-1562.

[35] S. Tonda, S. Kumar, S. Kandula, V. Shanker, J. Mater. Chem., 2014, 2, 6772-6780.

[36] Z. Chen, J. Zhang, S. K. Zheng, J. Ding, J. J. Sun, M. Dong, M. Abbas, Y. L. Chen, Z. Jiang, J. G. Chen, Mol. Catal, 2018, 444, 90-99.

[37] X. H. Liu, L. Stork, M. Speldrich, H. Lueken, R. Dronskowski, Chem. Eur. J., 2009, 15, 1558-1561.

[38] Y. Wang, Q. Jiang, J. K. Shang, J. Xu, Y. X. Li, Acta Phys. Chim. Sin., 2016, 32, 1913-1928.

[39] Q. Z. Ren, J. W. Huang, Z. A. Zhu, L. N. Ji, Y. T. Chen, J. Porphyrins Phthalocyanines, 2001, 5, 449-455.

[40] X. C. Wang, X. F. Chen, A. Thomas, X. Z. Fu, M. Antonietti, Adv. Mater., 2009, 21, 1609-1612.

[41] J. J. Zhu, Y. C. Wei, W. K. Chen, Z. Zhao, A. Thomas, Chem. Commun.,

\section{Graphical Abstract}

Chin. J. Catal., 2018, 39: 1263-1271 doi: 10.1016/S1872-2067(18)63063-3

Facile synthesis of Fe-containing graphitic carbon nitride materials and their catalytic application in direct hydroxylation of benzene to phenol

Bing Xue, Ye Chen, Yin Hong, Ding-Yang Ma, Jie Xu*, Yong-Xin Li * Changzhou University

Fe-containing graphitic carbon nitride materials were synthesized via one-step pyrolysis. Fe species are anchored and well dispersed on the $\mathrm{g}_{-} \mathrm{C}_{3} \mathrm{~N}_{4}$ support, which showed superior catalytic activity in the catalytic hydroxylation of benzene to phenol.

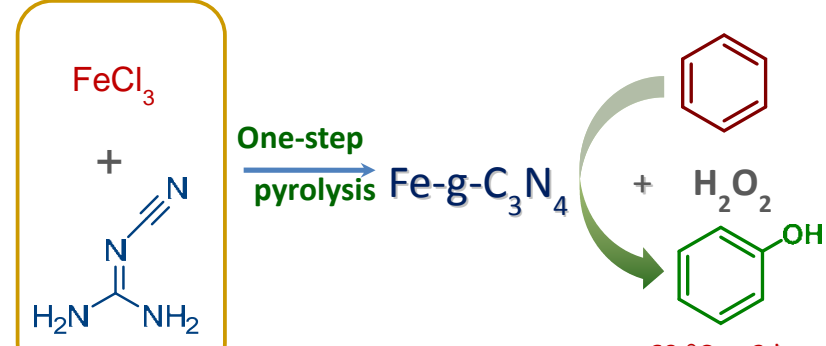

$60^{\circ} \mathrm{C}$ at $2 \mathrm{~h}$ Yield: $17.5 \%$ 
2010, 46, 6965-6967.

[42] X. C. Wang, K. Maeda, A. Thomas, K. Takanabe, G. Xin, J. M. Carlsson, K. Domen, M. Antonietti, Nat. Mater., 2009, 8, 76-80.

[43] Y. Oh, J. O. Hwang, E. S. Lee, M. Yoon, V. D. Le, Y. H. Kim, D. H. Kim, S. O. Kim, ACS Appl. Mater. Interfaces, 2016, 8, 25438-25443.

[44] B. Yue, Q. Y. Li, H. Iwai, T. Kako, J. H. Ye, Sci. Technol. Adv. Mater.,
2011, 12, 034401.

[45] C. Wang, L. Y. Hu, M. Y. Wang, Y. H. Ren, B. Yue, H. Y. He, Chin. J. Catal., 2016, 37, 2003-2008.

[46] J. Xu, F. Wu, Q. Jiang, Y. X. Li, Catal. Sci. Technol., 2015, 5, 447-454.

[47] L. X. Zhang, H. Wang, W. Z. Shen, Z. F. Qin, J. G. Wang, W. B. Fan, J. Catal., 2016, 344, 293-302.

\title{
简便方法合成含铁石墨相氮化碳材料及其催化苯直接羟基化制苯酚
}

\author{
薛 冰, 陈 晔, 洪颖, 马丁阳, 许 杰 $^{*}$, 李永昕 ${ }^{\#}$ \\ 常州大学石油化工学院, 江苏省绿色催化材料与技术重点实验室, 江苏常州 213164
}

摘要: 苯酚是一种重要的基本有机化工原料. 全球近 $90 \%$ 的苯酚都是经 “三步异丙苯法” 工艺合成而得, 但是该工艺存在 单程苯酚收率低 $(<5 \%)$ 、酸污染严重等不足. 同时由于联产丙酮, 苯酚的产量也受丙酮市场所制约. 由苯经氧化或羟基化 一步法合成苯酚是催化化学领域中一项极具挑战的课题. 由于苯分子较难活化, 而苯酚易于深度氧化, 因此研发和设计具 有高活性和高选择性的催化剂是该课题的研究核心.

因具有诸多特殊的理化性质, 石墨相氮化碳 $\left(\mathrm{g}-\mathrm{C}_{3} \mathrm{~N}_{4}\right)$ 作为一种新型碳质材料近年来在光催化、热催化、燃料电池和气 体吸附等领域展示出广阔的应用前景. $\mathrm{g}-\mathrm{C}_{3} \mathrm{~N}_{4}$ 的类石墨层基本单元为大 $\pi$ 共轭的三均三嗪环, 对苯分子具有良好的吸附和 活化能力. 目前, g- $\mathrm{C}_{3} \mathrm{~N}_{4}$ (尤其是具有高比表面的介孔材料) 在苯 Friedel-Crafts 烷基化和酰基化反应、苯的 $\mathrm{CO}_{2}$ 氧化等反应 中均显示了良好的催化活性. 尽管如此, 由于缺乏合适的氧化活性中心, 纯的 $\mathrm{g}-\mathrm{C}_{3} \mathrm{~N}_{4}$ 对苯直接羟基化几乎无催化活性.

本课题组曾将乙酰丙酮氧钒和氧化钒负载至介孔 $\mathrm{g}-\mathrm{C}_{3} \mathrm{~N}_{4}$, 发现该类催化剂在 $\mathrm{H}_{2} \mathrm{O}_{2}$ 参与的苯直接羟基化反应中, 苯转 化率高达 $18 \%$, 而苯酚选择性大于 $95 \%$. 然而, 此类介孔 $\mathrm{g}-\mathrm{C}_{3} \mathrm{~N}_{4}$ 均采用硬模板法合成, 制备周期长且需要 $\mathrm{HF}$ 溶液蚀刻氧 化硅模板. 另外, 钒基组分在介孔 $\mathrm{g}-\mathrm{C}_{3} \mathrm{~N}_{4}$ 表面也存在着部分溶脱现象.

本文以 $\mathrm{FeCl}_{3}$ 和二氰二胺为前驱体, 通过一步热解法直接合成了含铁的 $\mathrm{g}-\mathrm{C}_{3} \mathrm{~N}_{4}$ 材料 (Fe-g- $\mathrm{C}_{3} \mathrm{~N}_{4}$ ). 采用 $\mathrm{N}_{2}$ 吸附-脱附、 XRD、TG、FT-IR、UV-vis、XPS 光谱和 TEM 对材料的理化性质进行表征. 结果显示, Fe 的原位引入能显著提高 g- $\mathrm{C}_{3} \mathrm{~N}_{4}$ 的 比表面积和孔体积, 且使其依然保持石墨相结构. 同时, 富 $\mathrm{N}$ 的 $\mathrm{g}-\mathrm{C}_{3} \mathrm{~N}_{4}$ 材料能有效地针定 $\mathrm{Fe}$ 离子, 使其均匀地分散在载 体表面. 作为多相催化剂, Fe-g- $\mathrm{C}_{3} \mathrm{~N}_{4}$ 在 $\mathrm{H}_{2} \mathrm{O}_{2}$ 环境下对苯羟基化合成苯酚的反应表现出较高的催化活性. 当反应温度为 $60^{\circ} \mathrm{C}$, 其苯酚收率最高可达 $17.5 \%$, 且回收使用多次催化剂活性表现稳定. 与之前报道的含铁和负载氧化钒或乙酰丙酮氧 钒的 g- $\mathrm{C}_{3} \mathrm{~N}_{4}$ 催化剂材料相比, Fe-g- $\mathrm{C}_{3} \mathrm{~N}_{4}$ 催化剂制备工艺更加简便.

关键词: 苯; 羊基化; 石墨相氮化碳; 苯酚

收稿日期: 2018-01-19. 接受日期: 2018-03-19. 出版日期: 2018-07-05.

*通讯联系人. 电话: (0519)86330135; 电子信箱: shine6832@163.com

\#通讯联系人. 电话: (0519)86330135; 电子信箱: liyxluck@163.com

基金来源：国家自然科学基金 (21673024); 江苏省先进催化与绿色制造协同创新中心创新型人才支持项目 (ACGM2016-06-28); 省部共建煤炭高效利用与绿色化工国家重点实验室开放课题 (2017-K28); 江苏高校品牌专业建设工程 (PPZY2015B145).

本文的电子版全文由Elsevier出版社在ScienceDirect上出版(http://www.sciencedirect.com/science/journal/18722067). 